\title{
TELAAH TERHADAP PRESIDENTIAL THRESHOLD DALAM PEMILU SERENTAK 2019
}

\author{
Lutfil Ansori \\ Fakultas Syari'ah dan Hukum Universitas Islam Negeri Sunan Ampel Surabaya \\ J1. Jend. A. Yani 117 Surabaya \\ Email: fil.ansori@gmail.com
}

\begin{abstract}
Abstrak
Tulisan ini bertujuan untuk menelaah presidential threshold dalam hubungannya dengan pemilu serentak 2019. Pasca putusan Mahkamah Konstitusi Nomor 14/PUU$\mathrm{XI} / 2013$ yang mengamanatkan pemilu serentak menimbulkan pro kontra tentang pengaturan presidential threshold. Dalam prespektif konstitusi, menggunakan atau tidak menggunakan presidential threshold sesungguhnya tidak bertentangan dengan konstitusi, karena presidential threshold merupakan kebijakan hukum terbuka dari pembentuk Undang-Undang. Pembentuk Undang-Undang perlu memikirkan kembali tentang ketentuan presidential threshold terutama dalam hubungannya denga pemilu serentak, dengan mempertimbangkan kelebihan dan kekurangan dalam penerapan atau penghapusan presidential threshold, agar tujuan untuk memperkuat sistem presidensial tercapai. Adanya pemilu serentak sejatinya secara substansi telah menghapuskan ketentuan presidential threshold, sehingga persyaratan ambang batas untuk mencalonkan Presiden dan Wakil Presiden menjadi tidak relevan. Namun, apabila pembentuk Undang-Undang menghendaki adanya presidential threshold, maka jalan tengah yang dapat dipilih adalah menerapkan presidential threshold dengan menggunakan perolehan suara pemilu legislatif 2014 dengan catatan melembagakan koalisi.
\end{abstract}

Kata kunci: Presidential Threshold, Pemilu Serentak, Koalisi

\begin{abstract}
This paper aims to examine the presidential threshold in relation to the simultaneous general elections 2019. After the decision of the Constitutional Court Number 14/PUUXI/ 2013 which mandates the general election simultaneously raises the pros and cons of setting the presidential threshold. In the constitutional perspective, using or not using the presidential threshold is not contrary to the constitution, because the presidential threshold is an open legal policy of the legislator. The legislators need to rethink the provisions of the presidential threshold especially in relation to the simultaneous elections, taking into account the advantages and disadvantages of applying or abolishing the presidential threshold, in order for the purpose of strengthening the presidential system to be achieved. The existence of simultaneous general elections has substantially eliminated the provisions of the presidential threshold, so the threshold requirement to nominate the President and Vice President becomes irrelevant. However, if the legislators demand presidential threshold, the middle path that can be selected is to apply the presidential threshold by using the legislative election 2014 with a record of institutionalizing the coalition.
\end{abstract}

Keywords: Presidential Threshold, Simultaneous General Elections, Coalition 


\section{A. PENDAHULUAN}

1. Latar Belakang

Pemilihan Umum (selanjutnya disingkat pemilu) merupakan instrumen penting dalam negara demokrasi dengan sistem perwakilan. Pemilu adalah wujud nyata dari demokrasi prosedural. Indonesia sebagai negara hukum dengan pemerintahan yang demokratis mengakui pemilu sebagai pilar penting demokrasi yang harus diselenggarakan secara demokratis. Indonesia telah mengatur perihal pelaksanaan pemilu yang termaktub dalam UUD NRI Tahun 1945.

Konsep pemerintahan demokrasi adalah pemerintahan dari rakyat, oleh rakyat dan untuk rakyat. Oleh karena itu, rakyat memiliki kekuasaan tertinggi dalam negara demokrasi. Pasal 1 ayat (2) UUD NRI Tahun 1945 menegaskan bahwa kedaulatan berada di tangan rakyat dan dilaksanakan menurut Undang-Undang Dasar. Sebagai negara demokrasi, maka dapat dikatakan bahwa memilih dan dipilih dalam pemilu adalah deviasi dari kedaulatan rakyat yang merupakan bagian dari hak asasi setiap warga negara. ${ }^{1}$ Oleh karena itu, lazimnya di negara-negara yang menamakan diri sebagai negara demokrasi mentradisikan pemilihan umum untuk memilih pejabatpejabat publik di bidang legislatif dan eksekutif baik di pusat maupun di daerah. ${ }^{2}$

Pemilu telah diakui secara global sebagai sarana penyalur kedaulatan rakyat dalam bentuk partisipasi politik rakyat dalam menggunakan hak pilihnya. Teori demokrasi minimalis, sebagaimana dijelaskan oleh Joseph Shumpeter, menyebutkan bahwa pemilihan umum merupakan sebuah arena yang mewadahi kompetisi antara aktor-aktor politik yang meraih kekuasaan partisipasi politik rakyat untuk menentukan pilihan serta liberalisasi hak-hak sipil dan politik warga negara. ${ }^{3}$ Sedangkan menurut A. S. S. Tambunan, pemilu merupakan sarana atas pelaksanaan kedaulatan rakyat pada hakekatnya merupakan pengakuan dan perwujudan dari pada hak-hak politik rakyat dan sekaligus merupakan pendelegasian hak-hak tersebut oleh rakyat kepada wakilwakilnya untuk menjalankan pemerintahan. ${ }^{4}$

Pemilu merupakan pranata terpenting bagi pemenuhan tiga prinsip pokok demokrasi dalam pemerintahan yang berbentuk republik, yaitu kedaulatan rakyat, keabsahan pemerintahan dan pergantian pemerintahan secara teratur. Pemilu sebagai perwujudan demokrasi dianggap sebagai sarana atau mekanisme ideal dalam rangka proses peralihan kekuasaan secara damai dan tertib. Dengan penyelenggaraan pemilu, maka diharapkan proses peralihan kekuasaan dalam suatu negara akan dapat berjalan dengan baik.

Kegiatan pemilu merupakan sarana penyaluran hak asasi warga negara yang prinsipil. Oleh karena itu, dalam rangka pelaksanaan hak asasi warga negara menjadi suatu keharusan bagi pemerintah untuk menjamin terselenggaranya pemilu sesuai dengan jadwal ketatanegaraan yang ditentukan. ${ }^{5}$

${ }^{1}$ Nur Hidayat Sardini, Restorasi Penyelenggaraan Pemilu di Indonesia, Yogyakarta: Fajar Media Press, 2011, hlm. 1

2 A. Mukthie Fadjar, "Pemilu Yang Demokratis dan Berkualitas: Penyelesaian Hukum Pelanggaran Pemilu dan PHPU”, Jurnal Konstitusi, Vol. 6 No. 1 April 2009, hlm. 4

${ }^{3}$ P. Antonius Sitepu, Studi Ilmu Politik, Yogyakarta: Graha Ilmu, 2012, hlm. 177

${ }^{4}$ Titik Triwulan Tutik, Konstruksi Hukum Tata Negara Indonesia Pasca Amandemen UUD 1945, Jakarta: Kencana Prenada Media Group, 2011, hlm. 331

5 Jimly Asshiddiqie, Pengantar Ilmu Hukum Tata Negara, Jakarta: PT Raja Grafindo Utama, 2010, hlm. 416 
Dalam sejarah ketatanegaraan Indonesia, pelaksanaan pemilu telah dimulai pertama kali tahun 1955 di era Orde Lama dan dilanjutkan di era Orde Baru di bawah kepemimpinan Presiden Soeharto pada tahun 1971, 1977, 1982, 1987, 1992 dan 1997. Kemudian di era Reformasi pemilu dilaksanakan kembali pada 7 Juni 1999 untuk menggantikan produk pemilu 1997 yang dianggap tidak dipercaya lagi oleh rakyat. Setelah tahun 1999 Indonesia kembali melaksanakan pemilu setiap lima tahun sekali secara langsung untuk memilih anggota DPR, DPD, DPRD, serta Presiden dan Wakil Presiden yang dilaksanakan pada tahun 2004, 2009 dan 2014.

Menurut ketentuan UUD NRI Tahun 1945, yang termasuk dalam rezim pemilu adalah pemilihan anggota Dewan Perwakilan Rakyat (DPR), Dewan Perwakilan Daerah (DPD) ${ }^{6}$ dan Dewan Perwakilan Rakyat Daerah (DPRD) ${ }^{7}$ serta pemilihan Presiden dan Wakil Presiden. ${ }^{8}$ Namun dalam praktiknya selama ini, pemilihan anggota DPR, DPD dan DPRD ditempatkan secara terpisah dengan pemilihan Presiden dan Wakil Presiden dalam rezim pemilu legislatif. Sedangkan pemilihan Presiden dan Wakil Presiden ditempatkan dan diselenggarakan secara tersendiri dalam rezim pemilihan Presiden dan Wakil Presiden. ${ }^{9}$

Perhelatan pemilu legislatif dan pemilihan Presiden dan Wakil Presiden secara terpisah dianggap kurang mendukung bagi pelaksanaan demokrasi yang lebih efektif dan efisien. Kelemahan lain terlihat dari sisi waktu, besarnya biaya yang dibutuhkan dan juga tenaga yang harus dicurahkan oleh penyelenggara pemilu dalam rangka melaksanakan pesta demokrasi dalam waktu yang berbeda. Dalam konteks ini, negara memikul beban besar pengeluaran yang harus ditanggung dalam rangka menyelenggarakan pemilu legislatif dan pemilu Presiden dan Wakil Presiden yang dilaksanakan secara terpisah.

Setelah adanya Putusan Mahkamah Konstitusi Nomor 14/PUU-XI/2013 tentang Pengujian Undang-Undang Nomor 42 Tahun 2008 tentang Pemilihan Umum Presiden dan Wakil Presiden, lahir konsep pemilu serentak. Pemilu serentak adalah pelaksanaan pemilu legislatif dan pemilu Presiden dan Wakil Presiden yang dilaksanakan secara bersamaan.

Perlunya pemilu serentak merupakan hasil uji materi (judicial review) atas Undang-Undang No. 42 Tahun 2008 tentang Pemilihan Umum Presiden dan Wakil Presiden terhadap UUD Negara RI Tahun 1945. Mahkamah Konstitusi dalam putusannya menyatakan bahwa penyelenggaraan pemilu legislatif dan pemilu Presiden dan Wakil Presiden diselenggarakan secara bersamaan yang berlaku pada pemilu 2019 dan pemilu seterusnya. ${ }^{10}$

Mahakamah Konstitusi mengabulkan sebagian uji materi Undang-Undang No. 42 Tahun 2008, yaitu Pasal 3 ayat (5), Pasal 12 ayat (1) dan (2), Pasal 14 ayat (2), dan Pasal 112, tetapi Mahkamah Konstitusi tidak mengabulkan uji materi Pasal 9.

Pasal 9 Undang-Undang No. 42 Tahun 2008 menyatakan "Pasangan calon diusulkan oleh partai politik atau gabungan partai politik peserta pemilu yang

\footnotetext{
${ }^{6}$ Ketentuan mengenai hal ini dapat dilihat dalam Pasal 2 ayat (1), Pasal 19 ayat (1) serta Pasal 22C ayat (1) UUD Negara RI Tahun 1945

${ }^{7}$ Pasal 18 ayat (3) UUD Negara RI Tahun 1945

${ }^{8}$ Pasal 6A ayat (1) dan (2) UUD Negara RI Tahun 1945

9 Janpatar Simamora, "Menyongsong Rezim Pemilu Serentak", Jurnal Rechtsvinding, Vol. 3 No. 1, April 2014, hlm. 3

${ }^{10}$ Lihat Putusan Mahkamah Konstitusi No. 14/PUU-XI/2013 dalam perkara pengujian UndangUndang No. 42 Tahun 2008 tentang Pemilihan Umum Presiden dan Wakil Presiden terhadap UUD Negara RI Tahun 1945
} 
memenuhi persyaratan perolehan kursi paling sedikit 20\% (dua puluh persen) dari jumlah kursi DPR atau memperoleh $25 \%$ (dua puluh lima persen) dari suara sah nasional dalam pemilu anggota DPR, sebelum pelaksanaan pemilu Presiden dan Wakil Presiden". Hal ini kemudian disebut sebagai ambang batas perolehan suara bagi partai politik atau gabungan partai politik dalam mengusung calon Presiden dan Wakil Presiden, ${ }^{11}$ atau yang lebih dikenal dengan istilah presidential threshold.

Apabila presidential threshold ini dihubungkan dengan putusan Mahkamah Konstitusi No. 14/PUU-XI/2013 ini akan muncul persoalan, apakah pengaturan presidential threshold dalam Pasal 9 Undang-Undang No. 42 Tahun 2008 masih relevan diberlakukan dalam pemilu serentak 2019 ataukah perlu pengaturan baru yang menghilangkan mekanisme presidential threshold?.

Pada awalnya pengaturan presidential threshold oleh pembentuk UndangUndang adalah dalam rangka penguatan sistem presidensial. ${ }^{12}$ Itu sebabnya pemilu legislatif didahulukan dari pada pemilu Presiden dan Wakil Presiden. Hal inilah yang menarik untuk dikaji relevansi presidential threshold dalam pemilu serentak.

\section{Rumusan Masalah}

a. Apakah yang dimaksud dengan presidential threshold serta pengaturannya dalam Peraturan Perundang-Undangan Negara Kesatuan Republik Indonesia?

b. Bagaimanakah dengan pro kontra penerapan presidential threshold pada pemilu 2019 ?

\section{B. PEMBAHASAN}

\section{Presidential Threshold dalam Pemilu Presiden dan Wakil Presiden}

Hasil amandemen UUD 1945 jelas mengamanatkan pemilihan Presiden dan Wakil Presiden dilakukan secara langsung oleh rakyat. ${ }^{13}$ Akan tetapi yang kemudian menjadi perdebatan adalah persoalan mekanisme dan persyaratan calon Presiden dan Wakil Presiden terutama persyaratan presidential threshold yang diatur dalam UndangUndang Pilpres, yaitu Undang-Undang No. 42 Tahun 2008 tentang Pemilihan Umum Presiden dan Wakil Presiden.

Pengertian presidential threshold adalah pengaturan tingkat ambang batas dukungan dari DPR, baik dalam bentuk jumlah perolehan suara (ballot) atau jumlah perolehan kursi (seat) yang harus diperoleh partai politik peserta pemilu agar dapat mencalonkan Presiden dari partai politik tersebut atau dengan gabungan partai politik. ${ }^{14}$

Presidential threshold merupakan ketentuan tambahan mengenai pengaturan tentang syarat pencalonan Presiden dan Wakil Presiden dalam Pasal 6A ayat (2) yang menyatakan bahwa "Pasangan calon Presiden dan Wakil Presiden diusulkan oleh partai politik atau gabungan partai politik peserta pemilu sebelum pelaksanaan pemilu."

Secara tekstual, Pasal 6A ayat (2) UUD NRI Tahun 1945 tersebut memberikan ruang kepada semua partai politik peserta pemilu untuk mencalonkan Presiden dan Wakil Presiden. Hal ini dikarenakan partai politik sebagai pilar demokrasi dan

\footnotetext{
${ }^{11}$ Sodikin, "Pemilu Serentak (Pemilu Legislatif dengan Pemilu Presiden dan Wakil Presiden) dan Penguatan Sistem Presidensiil”, Jurnal Rechtsvinding, Vol. 3 No. 1, April 2014, hlm. 21

${ }^{12}$ Ibid.

${ }^{13}$ Pasal 6A UUD Negara RI Tahun 1945

${ }^{14}$ Sigit Pamungkas, Perihal Pemilu, Yogyakarta: Laboratorium Jurusan Ilmu Pemerintahan dan Jurusan Ilmu Pemerintahan Fisipol UGM, 2009, hlm. 19
} 
penghubung antara pemerintahan negara (the state) dengan warga negaranya (the citizens).

Pengaturan presidential threshold secara yuridis tertuang di dalam Pasal 9 Undang-Undang No. 42 Tahun 2008 tentang Pemilihan Umum Presiden dan Wakil Presiden. Dalam Undang-Undang ini ditegaskan bahwa :

"Pasangan calon diusulkan oleh partai politik atau gabungan partai politik peserta pemilu yang memenuhi persyaratan perolehan kursi paling sedikit $20 \%$ (dua puluh persen) dari jumlah kursi DPR atau memperoleh 25\% (dua puluh lima persen) dari suara sah nasional dalam pemilu anggota DPR, sebelum pelaksanaan pemilu Presiden dan Wakil Presiden"

Bila dikaji lebih dalam, sebenarnya kebijakan presidential threshold terkait dengan kebijakan ambang batas parlemen atau parlementary threshold yang menggantikan electoral threshold. ${ }^{15}$ Presidential threshold ini menjadi salah satu cara penguatan sistem presidensial melalui penyederhanaan partai politik. Tujuannya menciptakan pemerintahan yang stabil dan tidak menyebabkan pemerintahan yang berjalan mengalami kesulitan di dalam mengambil kebijakan dengan lembaga legislatif.

Penerapan presidential threshold menurut penilaian Mahkamah Konstitusi melalui putusan Nomor 3/PUU-VII/2009 merupakan kebijakan yang lebih demokratis karena tidak mengancam eksistensi partai politik dalam mengajukan pasangan calon Presiden dan Wakil Presiden. Presidential threshold dianggap tidak bertentangan dengan UUD NRI Tahun 1945 karena tidak menegasikan prinsip kedaulatan rakyat, serta tidak bersifat diskriminatif karena berlaku untuk semua partai politik. ${ }^{16}$ Sedangkan menurut putusan Mahkamah Konstitusi Nomor 14/PUU-XI/2013 ketentuan mengenai presidential threshold dianggap merupakan kebijakan hukum terbuka (open legal policy) dari pembentuk Undang-Undang. Istilah kebijakan hukum terbuka dapat dimaknai sebagai suatu kebebasan bagi pembentuk Undang-Undang untuk mengambil kebijakan hukum. ${ }^{17}$

Namun penerapan presidential threshold mengandung konsekuensi hilangnya kesempatan dan hak warga negara melalui partai politik yang tidak memenuhi besaran angka yang ditentukan untuk mengajukan calonnya. Oleh karena itu perlu diperhatikan, sesuai dengan prinsip demokrasi, dalam penentuan ambang batas besaran presidential threshold tidak boleh merugikan kelompok masyarakat tertentu terutama minoritas. Penentuan ambang batas presidential threshold harus memperhatikan keragaman masyarakat yang tercermin dalam aspirasi politik. ${ }^{18}$

Penentuan presidential threshold perlu dilakukan secara proporsional serta memperhatikan keseimbangan antara politik hukum penyederhanaan partai dan perlindungan terhadap keragaman politik. Penentuan besaran ambang batas presidential threshold tidak boleh dilakukan berdasarkan pertimbangan keuntungan dan kerugian yang akan didapat oleh partai politik. ${ }^{19}$

${ }^{15}$ Janedri M. Ghaffar, Politik Hukum Pemilu, Jakarta: Konstitusi Pres, 2012, hlm. 33

${ }^{16}$ I Dewa Made Putra Wijaya, "Mengukur Derajat Demokrasi Undang-Undang Nomor 42 Tahun 2008 tentang Pemilihan Umum Presiden dan Wakil Presiden", Jurnal IUS, Vol. II Nomor 6 Desember 2014, hlm. 564

17 Mardian Wibowo, "Menakar Konstitusionalitas sebuah Kebijakan Hukum Terbuka dalam Pengujian Undang-Undang”, Jurnal Konstitusi, Volume 12 Nomor 2, Juni 2015, hlm. 211

${ }^{18}$ I Dewa Made Putra Wijaya, Op.Cit., hlm. 564

${ }^{19}$ Ibid., hlm. 565 
Mahkamah Konstitusi melalui putusannya, yakni Putusan Nomor 14/PUU$\mathrm{XI} / 2013$, menegaskan bahwa ketentuan mengenai presidential threshold merupakan kebijakan hukum terbuka atau delegasi kewenangan terbuka yang dapat ditentukan sebagai legal policy oleh pembentuk Undang-Undang. Oleh karena itu, Mahkamah Konstitusi menyerahkan persoalan presidential threshold kepada pembentuk undangundang, yakni pemerintah dan DPR.

Dengan mengacu pada putusan Mahkamah Konstitusi tersebut dapat dimaknai bahwa penerapan presidential threshold dalam pemilu Presiden dan Wakil Presiden tidaklah bertentangan dengan konstitusi, demikian pula dengan penghapusan presidential threshold juga tidak bertentangan dengan konstitusi. Maka ada atau tidak adanya presidential threshold dalam pemilu Presiden dan Wakil Presiden sesungguhnya tetap konstitusional.

\section{Pro Kontra Penerapan Presidential Threshold dalam Pemilu Serentak 2019}

Putusan Mahkamah Konstitusi yang tidak mengabulkan judicial review Pasal 9 Undang-Undang No. 42 Tahun 2008 terkait presidential threshold menimbulkan dua tafsiran, yaitu pertama, presidential threshold dianggap masih diperlukan dalam pemilu serentak 2019, dan kedua, presidential threshold dianggap sudah tidak relevan lagi digunakan dalam pemilu serentak 2019.

Terkait hal ini Mahkamah Konstitusi menyerahkan kepada pembentuk UndangUndang. Mahkamah Konstitusi beranggapan bahwa pembentuk undang-undanglah yang berwenang menentukan apakah diperlukan atau tidak presidential threshold untuk pemilu Presiden dan Wakil Presiden 2019. ${ }^{20}$

Pada saat merumuskan amandemen UUD 1945, tidak ada ketentuan pasti tentang presidential threshold, sehingga pada saat itu rumusan yang disepakati adalah mendelegasikan kepada lembaga legislatif untuk mengaturnya dalam Undang-Undang. ${ }^{21}$ Maknanya, apabila pemilu Presiden dan Wakil Presiden dilaksanakan bersamaan dengan pemilu legislatif, maka presidential threshold masih dapat diterapkan. Demikian pula sebaliknya, presidential threshold dapat dihilangkan apabila pembentuk UndangUndang menghendakinya.

Artinya keberadaan ketentuan presidential threshold bergantung kepada politik hukum pembentuk Undang-Undang. Ketentuan lebih lanjut mengenai pemilihan umum serentak memang perlu dilaksanakan, karena terdapat hal-hal yang tidak dapat dirumuskan secara langsung dalam UUD 1945 karena sifatnya mudah untuk berubah dan sangat teknis.

Pro kontra penerapan presidential threshold kembali menyeruak seiring revisi Undang-Undang tentang Pemilihan Umum Presiden dan Wakil Presiden. Sampai saat ini DPR belum mendapatkan titik temu apakah pemilu serentak 2019 tetap menggunakan presidential threshold ataukah menghapuskan ketentuan presidential threshold. $^{22}$ Menggunakan presidential threshold atau menghapuskan presidential threshold dalam pemilu serentak 2019 yang akan datang tentu keduanya mengandung kelebihan dan kekurangan, terutama dalam hubungannya dengan penguatan sistem presidensial. Oleh karena itu, perlu tela'ah secara mendalam untuk tetap menggunakan

\footnotetext{
${ }^{20}$ Sodikin, Op.Cit., hlm. 26

${ }^{21}$ Ibid., hlm. 27

22 __ "Pembahasan Presidential Threshold Masih Buntu", http:// nasional.kompas.com/read/ 2017/07/ 04/16155851/pembahasan.presidential.threshold.masih.buntu, diakses tanggal 18 Juli 2017
} 
presidential threshold atau menghilangkan ketentuan presidential threshold ini, bukan berdasar pada pertimbangan politik jangka pendek.

Apabila dikaji mendalam, ada beberapa kelebihan dari penerapan presidential threshold dalam pemilu. Pertama, penerapan presidential threshold dalam pemilu dapat memunculkan figur Presiden dan Wakil Presiden yang kuat, karena Presiden dan Wakil Presiden terpilih akan mendapat basis dukungan politik yang besar di parlemen, sehingga pelaksanaan pemerintahan dapat berjalan efektif dan stabil. Dalam derajat tertentu, kondisi ini dapat memperkuat sistem presidensial yang dianut oleh Indonesia.

Kedua, penghapusan presidential threshold sebagai syarat pencalonan pemilu Presiden dan Wakil Presiden dapat menyebabkan parlemen cenderung dominan, sehingga memperlemah sistem presidensial. Ketiga, penerapan presidential threshold yang tetap tinggi memaksa partai politik atau gabungan partai politik menyeleksi calon Presiden dan Wakil Presiden dengan sungguh-sungguh, sehingga akan memunculkan Presiden dan Wakil Presiden yang berkualitas. Keempat, penerapan presidential threshold akan melahirkan koalisi untuk memperkuat pelaksanaan pemerintahan, sehingga akan membangun pemerintahan yang efektif.

Kelima, presidential threshold dalam pengajuan calon Presiden dan calon Wakil Presiden dimaksudkan untuk menyederhanakan sistem kepartaian. Partai politik pasca pemilihan umum akan membentuk dua poros, yaitu poros pemerintah sebagai pengusung dan poros oposisi. Sehingga dalam parlemen hanya akan ada dua kekuasaan dan partai-partai politik akan berafiliasi dengan partai lain. Dengan model ini, kinerja presiden sebagai eksekutif dalam hal penyelenggaraan pemerintahan akan semakin efektif.

Namun demikian dibalik beberapa kelebihan penerapan presidential threshold dalam pemilu serentak juga memiliki banyak kelemahan, antara lain: pertama, dengan adanya koalisi partai politik dalam mengusung calon Presiden dan Wakil Presiden sangat rentan terjadi tukar menukar kepentingan (politik transaksional). Dalam derajat tertentu koalisi partai politik yang seperti ini justru akan memperlemah sistem presidensial, karena Presiden tersandera oleh partai politik dalam koalisinya. Kedua, penerapan presidential threshold akan membatasi partai politik yang baru berpartisipasi dalam pemilihan umum serentak 2019 tidak dapat berkoalisi untuk mengusung calon Presiden dan Wakil Presiden, karena belum memiliki jumlah parliamentary threshold. Hal ini dapat menghilangkan hak partai politik untuk mengusung calon Presiden dan Wakil Presiden yang notabene hak tersebut dijamin dalam UUD NRI Tahun 1945. Ketiga, dalam prespektif konstitusi, sebagian pihak menilai bahwa penerapan presidential threshold bertentang dengan UUD NRI Tahun 1945. Presidential threshold dianggap telah menghilangkan makna pengakuan, jaminan perlindungan dan kepastian hukum yang adil, serta perlakuan yang sama bagi setiap warga negara di hadapan hukum. Lebih jauh dari itu, ketentuan tentang mekanisme syarat pencalonan pasangan Presiden dan Wakil Presiden dengan alasan sebagai cara untuk membentuk pemerintahan yang efektif serta sebagai solusi dalam rangka penyederhanaan atau rasionalisasi partai politik, telah menghilangkan hak warga negara untuk memilih secara cerdas dan efisien "political efficiency". ${ }^{23}$

Seiring dengan beberapa kelemahan penerapan presidential threshold diatas, beberapa ahli hukum tata negara menilai bahwa presidential threshold tidak relevan lagi diterapkan dalam pemilu serentak 2019. Meniadakan presidential threshold pada pemilu

${ }^{23}$ Putusan Mahkamah Konstitusi Nomor 14/PUU-XI/2008 dalam Perkara Pengujian UndangUndang terhadap Undang-Undang Dasar, tanggal 26 Maret 2013, hlm. 2 
serentak yang akan dilakukan pada 2019 dianggap sebuah keniscayaan, agar amanat UUD NRI Tahun 1945 terlaksana.

Pasal 6A UUD NRI Tahun 1945 tidak menentukan adanya ambang batas (presidential threshold) dalam Pemilu Presiden dan Wakil Presiden, yang ada hanyalah "Pasangan calon Presiden dan calon Wakil Presiden diajukan oleh partai politik atau gabungan partai politik peserta pemilihan umum". Di sini Pasal 6A ayat (2) UUD NRI Tahun 1945 apabila tidak ditafsirkan lain, maka pemberlakuannya tanpa ada hambatan. Sesuai dengan Pasal 6A ayat (2) UUD NRI Tahun 1945 dengan pemilu serentak, maka setiap partai politik peserta pemilihan umum dapat mengajukan pasangan calon Presiden dan Wakil Presiden tanpa syarat mempunyai sejumlah kursi tertentu di DPR.

Pasal 6A ayat (2) UUD NRI Tahun 1945 mengandung makna bahwa persyaratan yang berlaku bagi capres dan wapres adalah (1) capres dan wapres diajukan oleh partai politik baik sendiri-sendiri maupun bersama-sama dalam gabungan/koalisi partai politik; (2) semua partai politik dapat mengajukan pasangan capres dan wapres sepanjang memenuhi persyaratan sebagai peserta pemilu; dan (3) tidak ada penambahan syarat lain berupa threshold berapa pun besarnya. Pasal ini telah jelas maksudnya dan tidak memberi peluang bagi pembentuk undang-undang untuk membuat legal policy dengan menentukan presidential threshold sebagaimana diatur dalam Pasal 9 UU No. 42 Tahun 2008.

UUD NRI Tahun 1945 sebagai basic law hanya memberikan ruang kepada pembentuk Undang-Undang untuk mengatur lebih lanjut mengenai: (1) syarat-syarat untuk menjadi Presiden dan Wakil Presiden (Pasal 6 ayat (2) UUD NRI Tahun 1945) dan (2) tata cara pelaksanaan pemilu Presiden dan Wakil Presiden (Pasal 6A ayat (5) UUD N RI Tahun 1945.

Refly Harun menyebut bahwa syarat ambang batas pengajuan calon presiden atau presidential threshold yang diatur dalam Undang-Undang No. 42 Tahun 2008 tidak didasari argumentasi yang tepat. Penerapan presidential threshold untuk mengusung pasangan calon Presiden dan Wakil Presiden dianggapnya sebagai permainan politik partai partai besar. Penerapan presidential threshold dalam Undang-Undang Pilpres tidak masuk akal, karena UUD 1945 telah mengatur bahwa Presiden terpilih berdasarkan perolehan suara $50 \%$ plus satu dan tersebar di $20 \%$ provinsi. $^{24}$

Menurut Refly Harun, pernyataan yang menyatakan bahwa penerapan presidential threshold dilakukan untuk memperkuat sistem presidensial juga tidak bisa dibuktikan. Apabila Presiden yang terpilih berasal dari partai kecil, pembentukan kabinet juga pasti akan dilakukan secara koalisi. Contohnya adalah Partai Demokrat dengan suara minoritas pada tahun 2009 akhirnya mengajak partai Golkar masuk dalam kabinet meski dalam pemilihan Presiden harus berkompetisi. ${ }^{25}$ Menurut Syamsuddin Harris, secara teoritis basis legitimasi seorang presiden dalam skema sistem presidensial tidak ditentukan oleh formasi politik parlemen hasil pemilu legislatif. Lembaga presiden dan parlemen dalam sistem presidensial adalah dua intitusi terpisah yang memiliki basis legitimasi berbeda. ${ }^{26}$ Dengan demikian, sistem presidensial akan tetap efektif dan kuat dalam pemerintahan, meskipun pemilu serentak dilaksanakan tanpa harus ada

24 "Pengamat: Presidential Threshold Konspirasi Jahat Partai Besar", http://nasional .kompas.com/read/2014/01/25/1115549/Pengamat.Presidential.Threshold.Konspirasi.Jahat.Partai.Besar, diakses pada 17 Juli 2017

25 Ibid.

26 Syamsuddin Haris, "Salah Kaprah Presidential Threshold", http://nasional.sindonews .com/read/683795/18/salah-kaprah-presidential-threshold-1351561633, diakses pada 17 Juli 2017 
persyaratan ambang batas (presidential threshold) bagi partai politik pengusung calon Presiden dan Wakil Presiden.

Alasan ambang batas (presidential threshold) untuk menciptakan efektifnya pemerintahan oleh Presiden terpilih, penyederhanaan kepartaian dan menyeleksi calon Presiden dan Wakil Presiden juga tidak sepenuhnya tepat. Hal ini karena partai politik sebagai peserta pemilu sudah diseleksi secara ketat oleh KPU, sehingga partai politik yang lolos verifikasi yang ketat sebagai partai politik peserta pemilu yang kemudian mengusulkan calon Presiden dan Wakil Presiden. Penyeleksian partai politik peserta pemilu yang dilakukan oleh KPU sebagai bentuk penyederhanaan sistem kepartaian. ${ }^{27}$

Persyaratan presidential threshold dalam pengajuan pasangan calon Presiden dan Wakil Presiden, sebagaimana yang diatur dalam Pasal 9 Undang-Undang No. 42 Tahun 2008, dianggap tidak sejalan dengan prinsip sistem pemerintahan presidensial yang sesungguhnya, karena seharusnya pemilihan Presiden dan Wakil Presiden tidak memerlukan prasyarat ketercapaian kuota kursi di parlemen ${ }^{28}$. Karakteristik dasar sistem presidensial adalah keterpisahan antara eksekutif dan legislatif (executive is not depend on legislative). ${ }^{29}$ Praktik yang lazim di negara-negara yang menganut sistem presidensial adalah pemberlakuan ambang batas minimum bagi keterpilihan Presiden. Dengan kata lain, presidential threshold bukanlah untuk membatasi pencalonan Presiden, melainkan dalam rangka menentukan prosentase suara minimum untuk keterpilihan Presiden. ${ }^{30}$

Konsekuensi dari adanya penetapan ambang batas perolehan kursi di DPR bagi partai politik yang hendak mengajukan pasangan calon Presiden dan Wakil Presiden di dalam Pasal 9 Undang-Undang No. 42 Tahun 2008 dengan sendirinya mereduksi makna pemilu sebagai suatu mekanisme politik yang adil dan demokratis dalam menentukan pemimpin bangsa yang dipercaya, dan berimplikasi terhadap kualitas partisipasi politik rakyat dan upaya perlindungan bagi hak pemilih. ${ }^{31}$ Pembatasan calon berarti membatasi saluran politik pemilih dan dalam derajat tertentu mendorong pemilih tidak ikut berpartisipasi dalam pemilu Presiden dan Wakil Presiden, karena calon terbaik menurut mereka tidak dapat menjadi pasangan calon Presiden dan Wakil Presiden akibat pembatasan tersebut. Sebaliknya, penghapusan presidential threshold berarti membuka saluran politik rakyat dan dalam derajat tertentu meningkatkan partisipasi pemilih karena daya tarik calon Presiden dan Wakil Presiden yang lebih banyak pilihan alternatifnya. $^{32}$

Sejatinya, apabila pemilu legislatif dan pemilu Presiden dan Wakil Presiden diselenggarakan secara serempak dalam waktu yang bersamaan sebagaimana secara implisit terkandung dalam Pasal 22E ayat (2) juncto Pasal 6A ayat (2) UUD Negara RI Tahun 1945, maka mutatis mutandis ketentuan presidential threshold dalam Pasal 9 Undang-Undang No. 42 Tahun 2008 kehilangan relevansinya. Dengan demikian, Pasal 3 ayat (5) dan Pasal 9 Undang-Undang No. 42 Tahun 2008 bertentangan dengan sumber

${ }^{27}$ Sodikin, Op.Cit., hlm. 29

${ }^{28}$ Widaningsih, "Implikasi Yuridis atas Putusan Mahkamah Konstitusi tentang Penyelenggaraan Pemilihan Umum Serentak Tahun 2019”, Jurnal Cakrawala Hukum, Vol. 19 No. 1 Juni 2014, hlm. 98

${ }^{29}$ Djayadi Hanan, "Memperkuat Presidensialisme Multipartai di Indonesia: Pemilu Serentak, Sistem Pemilu, dan Sistem Kepartaian", http://puskapol.ui.ac.id/wp-content/uploads/2015/02/MakalahDjayadi-Hanan.pdf, hlm. 2, diakses pada 17 Maret 2016

${ }^{30}$ Widaningsih, Op.Cit., hlm. 98

${ }^{31}$ I Dewa Made Putra Wijaya, Op. Cit., hlm. 565

${ }^{32}$ Ibid., hlm. 566 
legitimasinya, yaitu Pasal 6A ayat (2) juncto Pasal 22E ayat (2) UUD Negara RI Tahun 1945.

Menurut Yusril Ihza Mahendra, adanya pemilu serentak sebagaimana putusan Mahkamah Konstitusi Nomor 14/PUU-XI/2013, maka adanya Pasal 9 Undang-Undang Pilpres soal ambang batas presiden (presidential threshold) secara tidak langsung tidak berlaku. ${ }^{33}$ Sehingga setiap partai politik peserta pemilu dapat mencalonkan Presiden dan Wakil Presiden. Dalam situasi yang demikian, sisi positif dari kondisi ini adalah bahwa seluruh partai politik memiliki peluang dan kesempatan yang sama untuk mengajukan calon Presiden dan Wakil Presiden. ${ }^{34}$

\section{Jalan Tengah Penerapan Presidential Threshold dalam Pemilu Serentak 2019}

Sebagaimana ditegaskan dalam uraian diatas, bahwa penerapan atau penghapusan presidential threshold dalam pemilu serentak 2019 tidak bertentangan dengan konstitusi. Maka jalan tengah yang dapat diambil adalah dengan mempertimbangkan kelebihan dan kekurangan masing-masing dalam hubungannya dengan penguatan sistem presidensial.

Menerapkan presidential threshold dalam pemilu serentak 2019 akan menemui persolan yang cukup serius setidaknya dalam dua hal, yaitu tentang keberadaan koalisi dan patokan ambang batas.

1) Keberadaan Koalisi

Partai politik yang tidak memenuhi ambang batas akan dipaksa untuk berkoalisi dengan partai politik lain. Koalisi ini sejatinya dimaksudkan agar Presiden terpilih mempunyai basis dukungan di parlemen yang kuat, sehingga pemerintahan dapat berjalan dengan efektif. Namun, keberadaan koalisi seringkali justru menimbulkan persoalan baru yang lebih serius, yakni politik transaksional. Keharusan koalisi membuka ruang partai politik untuk tawar menawar kepentingan, baik kepentingan untuk mendapatkan jatah kursi menteri dan kepentingan-kepentingan lain yang berujung pada politik transaksional. Koalisi dengan model seperti ini tidak akan memperkuat sistem presidensial, tetapi malah memperlemah sistem presidensial. Karena Presiden seringkali tersandera oleh partai politik koalisi manakala kebijakan Presiden tidak sejalan dengan keinginan partai dalam koalisi.

Koalisi yang dibangun dalam sistem kepartaian di Indonesia selama ini tidak menunjukkan koalisi permanen, yakni koalisi partai politik yang didasari pada ideologi, cita-cita, dan visi yang sama untuk kepentingan bangsa dan negara dalam jangka panjang. Sehingga sering ditemukan partai politik pendukung pemerintah dalam perjalanannya menyeberang menjadi partai oposisi, dan begitu sebaliknya partai oposisi berubah haluan di tengah jalan menjadi partai pendukung pemerintah. Model koalisi seperti ini tidak akan mendukung penguatan sistem presidensial, karena basis dukungan terhadap Presiden dapat berubah dan berganti haluan sewaktu-waktu.

Oleh karena itu, jalan tengah terhadap persoalan ini adalah dengan melembagakan koalisi. Yang dimaksud melembagakan koalisi adalah membuat koalisi permanen, setidaknya untuk jangka waktu lima tahun. Sehingga koalisi yang dibangun sejak awal ketika mengusung calon Presiden dan Wakil Presiden tidak terbelah ditengah jalan. Dengan demikian, peta kekuasaan parlemen sudah dapat diketahui sejak awal pencalonan Presiden dan Wakil Presiden. Pola ini juga dapat menjadi jalan tengah atas

\footnotetext{
${ }^{33}$ Lihat alasan Pemohon dalam Putusan Mahkamah Konstitusi No. 108/PUU-XI/2013

${ }^{34}$ Janpatar Simamora, Op.Cit., hlm. 15
} 
persoalan multi partai di Indonesia yang dianggap tidak sejalan dengan sistem presidensial. Partai-partai akan berkoalisi dengan partai lain secara permanen setidaknya dalam waktu lima tahun. Kondisi ini akan memaksa partai politik untuk berkoalisi berdasarkan ideologi, visi, dan cita-cita partai, karena setelah berkoalisi partai politik tidak dapat berpindah haluan setidaknya dalam jangka waktu lima tahun.

Untuk menjamin keberadaan lembaga koalisi, konsep melembagakan koalisi ini perlu dituangkan dalam peraturan perundang-undangan, yakni Undang-Undang Partai Politik, Undang-Undang Pemilihan Umum Presiden dan Wakil Presiden, dan peraturan perundang-undangan lain yang terkait.

2) Patokan Ambang Batas

Persoalan lain yang ditemui dalam penerapan presidential threshold di pemilu serentak 2019 adalah persoalan ambang batas, yakni pertama, berapa jumlah ambang batas yang ditentukan, dan kedua, ambang batas tersebut diambilkan dari mana.

Terhadap persoalan yang pertama, maka sepenuhnya bergantung pada politik hukum pembentuk Undang-Undang. Apakah akan digunakan ambang batas 20 persen, 15 persen, atau 10 persen dari perolehan kursi di legislatif bergantung kepada kebijakan yang diambil oleh DPR bersama dengan pemerintah. Terhadap persoalan yang kedua, maka jawaban yang paling mungkin adalah menggunakan ambang batas perolehan suara pada pemilu legislatif tahun sebelumnya, dalam hal ini pemilu legislatif tahun 2014. Meskipun kondisi ini tidak ideal karena situasi politik yang tentu sangat berbeda antara tahun 2014 dengan 2019 misalnya jumlah partai, muculnya partai-partai baru dan lain-lain, namun untuk menerapkan presidential threshold dalam pemilu serentak 2019 dapat menggunakan ambang batas pemilu legislatif 2014.

Dari uraian diatas, jalan tengah yang dapat diterapkan dalam pemilu serentak 2019 adalah pertama, menerapkan presidential threshold dengan menggunakan perolehan suara pemilu legislatif 2014 dengan catatan melembagakan koalisi. Kedua, menghapuskan ketentuan presidential threshold dengan membuka ruang seluas-luasnya kepada partai politik untuk mengusung calon Presiden dan Wakil Presiden dengan catatan memberikan pengetatan terhadap syarat-syarat menjadi calon Presiden dan Wakil Presiden untuk mendorong munculnya calon Presiden dan Wakil Presiden yang berkualitas. Pengetatan terhadap syarat calon Presiden dan Wakil Presiden ini dapat dituangkan di dalam Undang-Undang tentang Pemilihan Umum Presiden dan Wakil Presiden.

\section{SIMPULAN}

Penerapan presidential threshold dalam pemilu serentak 2019 menimbulkan pro kontra yang keduanya mempunyai basis alasan masing-masing. Menelaah pro kontra presidential threshold dalam pemilu serentak melahirkan kesimpulan bahwa adanya putusan Mahkamah Konstitusi Nomor 14/PUU-XI/2013 yang mengamanatkan pemilu serentak sejatinya secara substansi telah menghapuskan sistem presidential threshold, sehingga persyaratan ambang batas untuk mencalonkan Presiden dan Wakil Presiden menjadi tidak relevan dalam pemilu serentak 2019. Pembentuk Undang-Undang perlu memikirkan kembali pengaturan presidential threshold. Pengaturan presidential threshold perlu ditinjau kembali dalam merumuskan Undang-Undang tentang Pemilihan Umum Presiden dan Wakil Presiden, sehingga tidak bertentangan dengan amanat konstitusi yaitu UUD NRI Tahun 1945 terutama Pasal 6A ayat (2). Apabila pembentuk Undang-Undang menghendaki untuk tetap menggunakan presidential threshold dalam pemilu serentak 2019, maka jalan tengah yang dapat diambil adalah menerapkan 
presidential threshold dengan menggunakan perolehan suara pemilu legislatif 2014 dengan catatan melembagakan koalisi.

\section{DAFTAR PUSTAKA}

\section{Buku:}

Janedri M. Ghaffar. 2012. Politik Hukum Pemilu. Jakarta: Konstitusi Pres

Jimly Asshiddiqie. 2010. Pengantar Ilmu Hukum Tata Negara. Jakarta: PT Raja Grafindo Utama

Nur Hidayat Sardini. 2011. Restorasi Penyelenggaraan Pemilu di Indonesia. Yogyakarta: Fajar Media Press

P. Antonius Sitepu. 2012. Studi Ilmu Politik, Yogyakarta: Graha Ilmu

Sigit Pamungkas, Perihal Pemilu. 2009. Yogyakarta: Laboratorium Jurusan Ilmu Pemerintahan dan Jurusan Ilmu Pemerintahan Fisipol UGM

Titik Triwulan Tutik, Konstruksi Hukum Tata Negara Indonesia Pasca Amandemen UUD 1945, Jakarta: Kencana Prenada Media Group, 2011

\section{Jurnal:}

A. Mukthie Fadjar, "Pemilu Yang Demokratis dan Berkualitas: Penyelesaian Hukum Pelanggaran Pemilu dan PHPU”, Jurnal Konstitusi, Vol. 6 No. 1, April 2009

I Dewa Made Putra Wijaya, "Mengukur Derajat Demokrasi Undang-Undang Nomor 42 Tahun 2008 tentang Pemilihan Umum Presiden dan Wakil Presiden”, Jurnal IUS, Vol. II Nomor 6 Desember 2014

Janpatar Simamora, "Menyongsong Rezim Pemilu Serentak", Jurnal Rechtsvinding, Vol. 3 No. 1, April 2014

Mardian Wibowo, "Menakar Konstitusionalitas sebuah Kebijakan Hukum Terbuka dalam Pengujian Undang-Undang”, Jurnal Konstitusi, Volume 12 Nomor 2, Juni 2015

Nazaruddin, "Kebijakan Multipartai Sederhana Dalam Undang-Undang Pemilu”, Jurnal Konstitusi, Volume 1 Nomor 1, Juni 2009

Sodikin, "Pemilu Serentak (Pemilu Legislatif dengan Pemilu Presiden dan Wakil Presiden) dan Penguatan Sistem Presidensiil”, Jurnal Rechtsvinding, Vol. 3 No. 1, April 2014

Widaningsih, "Implikasi Yuridis atas Putusan Mahkamah Konstitusi tentang Penyelenggaraan Pemilihan Umum Serentak Tahun 2019”, Jurnal Cakrawala Hukum, Vol. 19 No. 1 Juni 2014 


\section{Peraturan Perundang-undangan dan Putusan Pengadilan:}

\section{UUD NRI Tahun 1945}

Undang-Undang No. 42 Tahun 2008 tentang Pemilihan Umum Presiden dan Wakil Presiden

Putusan Mahkamah Konstitusi No. 14/PUU-XI/2013 dalam perkara pengujian UndangUndang No. 42 Tahun 2008 tentang Pemilihan Umum Presiden dan Wakil Presiden terhadap UUD Negara RI Tahun 1945

Putusan Mahkamah Konstitusi No. 3/PUU-VII/2009 dalam perkara pengujian UndangUndang Nomor 10 Tahun 2008 tentang Pemilihan Umum Anggota DPR, DPD, dan DPRD terhadap UUD Negara RI Tahun 1945

Putusan Mahkamah Konstitus No. 51-52-59/PUU-VI/2008 dalam perkara pengujian Undang-Undang Nomor 42 Tahun 2008 tentang Pemilihan Umum Presiden dan Wakil Presiden terhadap UUD Negara RI Tahun 1945

\section{Internet:}

Djayadi Hanan, "Memperkuat Presidensialisme Multipartai di Indonesia: Pemilu Serentak, Sistem Pemilu, dan Sistem Kepartaian", http://puskapol.ui.ac.id/wpcontent/uploads/2015/02/Makalah-Djayadi-Hanan.pdf

Syamsuddin Haris, "Salah Kaprah Presidential Threshold", http://nasional.sindonews.com/read/683795/18/salah-kaprah-presidential-thresho $\underline{\text { ld-1351561633 }}$

, "Pengamat: Presidential Threshold Konspirasi Jahat Partai Besar", http://nasional. kompas.com/read/2014/01/25/1115549/Pengamat.Presidential.Threshold.Konspir asi. Jahat.Partai.Besar

"Pembahasan Presidential Threshold Masih Buntu", http:// nasional.kompas.com/read/

2017/07/04/16155851/pembahasan.presidential.threshold.masih.buntu 